\title{
Hopkinsiaceae and Lyginiaceae, two new families of Poales in Western Australia, with revisions of Hopkinsia and Lyginia
}

\author{
Barbara G. Briggs and L.A.S. Johnson ${ }^{\dagger}$
}

\begin{abstract}
Briggs, Barbara G. E Johnson, L.A.S. (Royal Botanic Gardens, Mrs Macquaries Road, Sydney, NSW 2000, Australia) 2000. Hopkinsiaceae and Lyginiaceae, two new families of Poales in Western Australia, with revisions of Hopkinsia and Lyginia. Telopea 8 (4): 477-502. Hopkinsia and Lyginia are excluded from Restionaceae and the new families Hopkinsiaceae and Lyginiaceae established. DNA sequence data from the chloroplast gene $r b c \mathrm{~L}$, the $t r n \mathrm{~L}$ intron and $t r n \mathrm{~L}-t r n \mathrm{~F}$ intergenic spacer indicate that these genera are more closely allied to Anarthriaceae than to Restionaceae, although differing markedly from the former in vegetative morphology and anatomy. The contrasting results of cladistic analyses of DNA sequence data and morphological data are discussed, as are the reasons for excluding these genera from Restionaceae and Anarthriaceae. Extensive descriptions of the new families are given and a key provided to these and related families. The features that they share with Restionaceae are considered to be largely plesiomorphic within Poales or associated with their occurrence, like many Restionaceae, in conditions of seasonal drought. Occurring in a region of great diversity of Restionaceae, their distinctiveness was overlooked until the new DNA evidence became available. Distinctive features for Hopkinsia include the ovary structure, style with stigmatic branches that are themselves branched, fleshy pedicels, and fruit with both woody and fleshy layers. Distinctive for Lyginia are the oblique epidermal cells and stomates, distinctive chlorenchyma structure, fused staminal filaments, seed ornamentation and presence of unusual chemical constituents (allose, allosides and fructan-type oligosaccharides). Both genera also differ from Restionaceae in having 2-lobed, 4-sporangiate anthers and pollen of graminoid type. Two new species, H. adscendens from south coastal Western Australia and L. excelsa from the Cataby region north of Perth are described, and the differences in reproductive biology between the species of Lyginia are noted. Both the species of Hopkinsia and L. adscendens have vulnerable or endangered conservation status. The chromosome number $2 n=18$ is reported in H. adscendens.
\end{abstract}

\section{Introduction}

Although Hopkinsia and Lyginia have until now been included within Restionaceae, they have long been recognised as differing substantially from other members of that family. Gilg-Benedict (1930) placed them, with Anarthria and Ecdeiocolea, in Diplantherae, characterised by bithecate anthers, whereas all other Restionaceae have unithecate anthers and constituted the Haplantherae. Cutler and Shaw (1965) removed Anarthria and Ecdeiocolea from Restionaceae establishing two new families. In the absence of molecular data, we have long been aware of major differences between Hopkinsia and Lyginia and all other genera then included in Restionaceae (Johnson \& Briggs 1981), although we regarded them as basal groups within that family. More recently, since DNA data became available, we have foreshadowed recognition of the new families here described (Linder et al. 1998; Briggs \& Johnson 1999; Briggs et al. 2000; Briggs 2000). 


\section{Evidence supporting the recognition of new families}

Members of the same plant family can be expected to form a monophyletic group separate from related families; they should also share synapomorphic features by which the family can be characterised and contrasted with other families. Criteria of relationship and morphology must both be met.

In the present case, in brief, molecular evidence requires the exclusion of Hopkinsia and Lyginia from Restionaceae. Morphological evidence gives no basis for these genera being placed in Anarthriaceae and similarly fails to give a basis for uniting them in a single new family. The analyses of morphological and DNA data in this case produce contradictory results, but these appear to indicate a degree of homoplasious and convergent morphological evolution, rather than implying substantially different phylogenies.

The justification for recognising the new families Hopkinsiaceae and Lyginiaceae depends on establishing that:

(1) Hopkinsia and Lyginia are not correctly placed within the Restionaceae;

(2) synapomorphies shared with Anarthriaceae are not sufficient for them to be included in that family; and

(3) they are not appropriately placed together in a single new family.

(1) Exclusion from Restionaceae

The major evidence for exclusion of Hopkinsia and Lyginia from Restionaceae comes from analysis of DNA sequence data. Cladistic parsimony analysis of DNA sequences of the chloroplast gene $r b c \mathrm{~L}$ and of the $\operatorname{trn} \mathrm{L}$ intron, together with the $\operatorname{trn} \mathrm{L}-t r n \mathrm{~F}$ intergenic spacer, does not associate Hopkinsia and Lyginia with other genera referred to Restionaceae but shows a robust clade of these two genera with Anarthria (Fig. 1, modified from Briggs et al. 2000). This clade has 100\% jackknife support in separate cladistic analyses of each of the two regions of the chloroplast DNA, as well as of the combined data. In addition, the clade is marked by two indels in the trn $\mathrm{L}$ intron, an insertion of five bases and a deletion of three; these indels show no homoplasy among other members of the Poales studied. This molecular evidence comes wholly from chloroplast DNA but is supported by the highly conserved $r b c \mathrm{~L}$ gene, as well as a less conserved region of DNA that is now being widely used in phylogenetic studies (e.g. Bayer \& Starr 1998) and has given moderately well resolved trees in our studies of Poalean families. The consensus trees from the combined DNA data places the Anarthria clade as sister to the Restionaceae clade (Restionaceae with Centrolepidaceae). Data from $r b c \mathrm{~L}$ alone similarly distinguish these and the Poaceae clade (each with 100\% jackknife support) but places them (and several other families) at an unresolved polychotomy.

We interpret the results from DNA studies (Fig. 1) as giving a clear indication that Anarthria, Hopkinsia and Lyginia form a clade. These genera, however, fail to associate in a cladogram based on morphological data (Fig. 2, modified from Linder et al. 2000); instead Anarthria, Lyginia and Hopkinsia emerge successively at the base of Restionaceae. [The two cladograms also show contrasting positions for the Centrolepidaceae; the affinities of that family are being further investigated and are not discussed in the present paper. Similarly, the two trees show differences in the positions of various genera within Australian Restionaceae and these discrepancies are being further studied.] Such a contrasting result for Hopkinsia and Lyginia could arise from homoplasious and indeed convergent change in morphological characters, perhaps during evolution under similar environmental conditions. Constraining the morphological tree so that Hopkinsia and Lyginia associate with Anarthria, rather than 


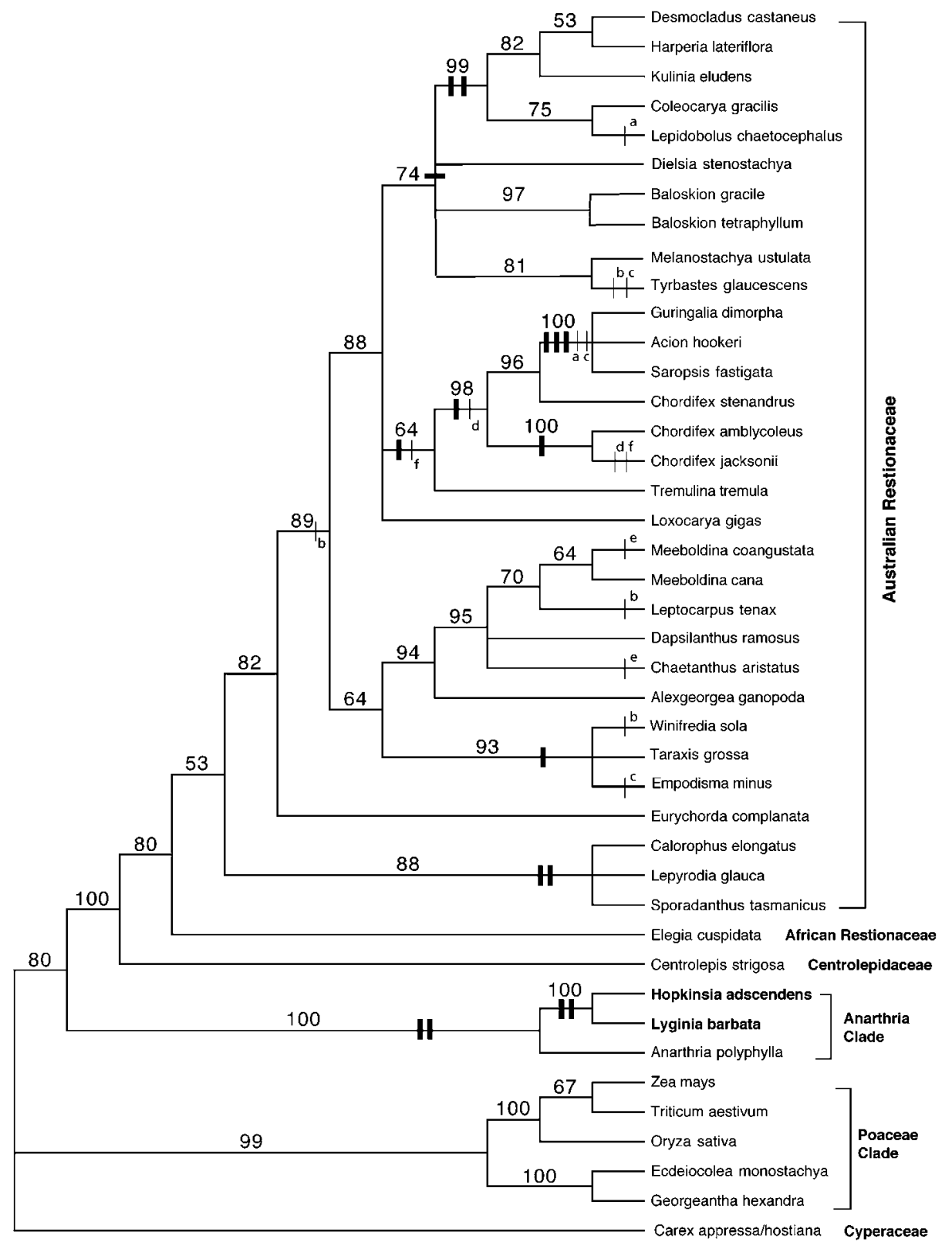

Fig. 1. Jackknife consensus tree from parsimony analysis of combined chloroplast DNA sequence data $(r b c \mathrm{~L}, t r n \mathrm{~L}$ intron and $t r n \mathrm{~L}-t r n \mathrm{~F}$ intergenic spacer) for representative species. Support indices are shown and indels supporting clades are indicated by cross-bars; homoplasious indels are shown by narrow bars and are identified by letters. The outgroup consists of a combination of the $r b c \mathrm{~L}$ sequence of Carex hostiana with the trn $\mathrm{L}-t r n \mathrm{~F}$ region of C. appressa. (Modified from Briggs et al. 2000). 
with Restionaceae, increases tree length by four steps to 305 steps (Linder et al. 2000). If, on the other hand, the molecular tree is constrained to match the morphological tree by placing these genera as basal but ungrouped, tree length increases from 2742 steps to 2807 , an increase of 65 steps. In addition, both the two indels common to the three genera would become homoplasious, requiring an additional four innovations.

Our morphological studies suggest that most of the characters that are common to Restionaceae, Hopkinsia and Lyginia (Table 1), apart from dioecy and some aspects of culm anatomy, are plesiomorphic within Poales or are readily interpreted as homoplasies associated with occurrence in regions of low soil fertility and seasonal drought. Indeed, within the Poales, one of the most conspicuous similarities shared by Hopkinsia, Lyginia and Restionaceae is the xeromorphic habit with reduced leaf laminae, so that the culms are the principal photosynthetic organs. Some further relevant characters may arise from embryology (c.f. Linder \& Rudall 1993) and from inversions within the chloroplast DNA (Doyle et al. 1992), but information on these features is lacking for Hopkinsia and Lyginia.

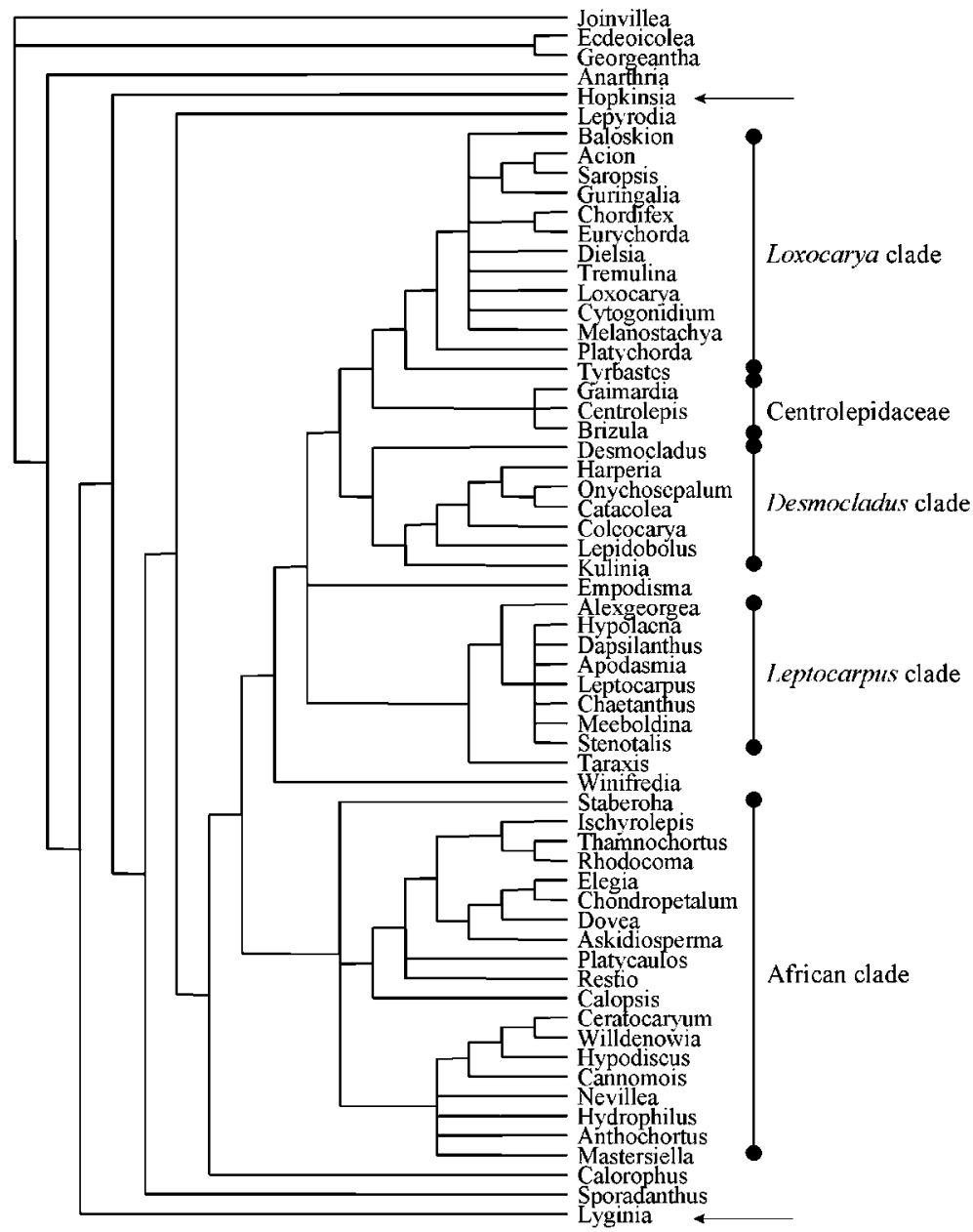

Fig. 2. Strict consensus tree from parsimony analysis of morphological data for genera. Joinvillea (Joinvilleaceae) forms the outgroup. Arrows mark Lyginia and Hopkinsia. (Modified from Linder et al. 2000). 
Table 1. Morphological and phytochemical characters of Hopkinsia, Lyginia, Anarthria and Restionaceae.

+ presence of character; - absence; * considered to be an apomorphic condition; ** autapomorphy, i.e. sole occurrence among these taxa (some characters are marked as autapomorphies although common to other taxa, e.g. 2-sporangiate anthers shared by Restionaceae and (entrolepidaceae). Character states are defined so that conditions considered to be apomorphic are scored ' + '. Several characters of related organs are listed together where these are fully correlated among these taxa. Rare conditions are in parentheses.

\begin{tabular}{|c|c|c|c|c|}
\hline Character & Hopkinsia & Lyginia & Anarthria & Restionaceae \\
\hline dioecy & $+^{*}$ & $+^{*}$ & $+^{*}$ & $+* /(-)$ \\
\hline root hairs not persistent and lignified & - & - & - & $+/-$ \\
\hline $\begin{array}{l}\text { culm sclerenchyma cylinder and } \\
\text { parenchyma sheath }\end{array}$ & $+^{*}$ & $+^{*}$ & - & $+^{*}$ \\
\hline leaf lamina reduced & $+^{*}$ & $+^{*}$ & - & $+^{*}$ \\
\hline leaves equitant & - & - & $+* *$ & - \\
\hline oblique epidermal cells and stomates & - & $+* *$ & - & - \\
\hline $\begin{array}{l}\text { 'false pillar cells' in chlorenchyma, } \\
\text { not around substomatal cavities }\end{array}$ & - & $+* *$ & - & - \\
\hline flowering culms not branched & - & $+^{*}$ & $+^{*}$ & $+* /-$ \\
\hline inflorescence with caducous spathe & - & - & $+* *$ & - \\
\hline hyaline perianth and bracts & $+^{*}$ & - & - & $+* /-$ \\
\hline stamen filaments fused & - & $+* *$ & - & - \\
\hline anthers 2-sporangiate & - & - & - & $+* *$ \\
\hline pollen grain without graminoid annulus & - & - & - & $+* *$ \\
\hline ovary unilocular & $+^{*}$ & - & - & $+* /-$ \\
\hline stigmatic branches further branched & $+* *$ & - & - & - \\
\hline fleshy pedicel; drupaceous fruit & $+* \star$ & - & - & - \\
\hline seed with spinules and median flange & - & $+* *$ & - & - \\
\hline $\begin{array}{l}\text { mitotic metaphase chromosome length } \\
\text { (length of individual chromosomes) }\end{array}$ & $1.7-2.7 \mu \mathrm{m}$ & $3-4 \mu \mathrm{m}$ & $3-7 \mu \mathrm{m}$ & $0.7-2 \mu \mathrm{m}$ \\
\hline starch in megagametophyte & $?$ & + & - & + \\
\hline fructan oligosaccharides in rhizome & - & $+* *$ & & - \\
\hline silica absent from culm & + & + & + & - \\
\hline rhombic crystals present & - & $+^{*}$ & $+^{*}$ & - \\
\hline allose oligosaccharides present & - & $+* *$ & - & - \\
\hline flavones present & - & - & + & $+/-$ \\
\hline
\end{tabular}

\section{(2) Exclusion from Anarthriaceae}

Anarthria was separated from Restionaceae (Cutler \& Shaw 1965) largely on the basis of its fundamentally different culm anatomy. It lacks a sclerenchyma cylinder and parenchymatous sheath isolating the chlorenchyma from the pith, having separate sclerenchyma masses that surround each vascular bundle. The leaves are not reduced but are highly distinctive in being equitant, with one margin representing the keel of 
a folded and fused structure. Hopkinsia and Lyginia differ strikingly from Anarthria in these features of vegetative morphology and anatomy. The culms have both a sclerenchyma cylinder and parenchyma sheath. The leaves are not equitant; there is a much reduced dorsiventral lamina, often in the form of a mucro or awn at the apex of the sheath. The leaf laminae of juvenile plants or those resprouting after fire are often less reduced, but the lamina always has dorsiventral structure. The inflorescences also lack a large enclosing spathe, as shown by Anarthria. All three genera possess sandbinding roots with long, persistent and lignified root hairs, but Pate and Delfs (1999) indicate that this character may be plesiomorphic and loss of this epidermis in many Restionaceae is considered to be apomorphic.

Although the analyses of DNA data indicate a close relationship between Anarthria, Hopkinsia and Lyginia, if these genera lack morphological synapomorphies they fail to form a family with recognisable apomorphic characteristics. The paucity of synapomorphies is shown by the tree based on morphological data (Fig. 2), in which the three genera are placed ungrouped at the base of the tree. Several of the features that these genera share (Table 1) appear to be plesiomorphic in the Poales; these include the 2-lobed, 4-sporangiate anthers and pollen with graminoid-type aperture. The 23 characters (or character groups) listed in Table 1 reveal only the absence of silica in the culms as a probable synapomorphy supporting the group (Anarthria, Hopkinsia, Lyginia) in contrast to Restionaceae.

\section{(3) One new family or two?}

Within the Anarthria clade, DNA data show (Hopkinsia, Lyginia) as sister to Anarthria (Fig. 1) but, as noted above, they fail to group in trees based on analysis of morphological features (Fig. 2). Hopkinsia and Lyginia present very dissimilar morphological features, and many of the features they share are plesiomorphic. They share the synapomorphies of culm sclerenchyma cylinder and parenchyma sheath (homoplasious with conditions in Restionaceae), but these features do not convincingly associate them as a family in the face of many notable autapomorphies (Table 1).

Distinctive autapomorphies for Hopkinsia include the thickened pedicel, long stigmatic branches that are themselves branched, and fruit with both fleshy and woody layers. Other features that are paralleled in some Restionaceae but are autapomorphic within the Anarthria clade are the hyaline perianth and bracts, reduced gynoecium with a single loculus and style, and indehiscent fruit. Linder (1992) observed that the ovary of Hopkinsia differs in structure from other unilocular ovaries in Restionaceae.

Lyginia is marked by epidermal cells and stomates that are oblique to the culm surface, chlorenchyma of alternating blocks of thin-walled photosynthetic cells and thickwalled non-photosynthetic cells ('false pillar cells', not bordering substomatal cavities and not homologous with Restionaceous pillar cells), fused staminal filaments, unique seed ornamentation of cuticular spinules and a cuticular flange encircling the seed in the median vertical plane.

We conclude, from the molecular and morphological evidence now available, that Hopkinsia, and Lyginia cannot satisfactorily be included in either Restionaceae or Anarthriaceae but that they do not form a single, well defined, new family. The families Hopkinsiaceae and Lyginiaceae are therefore here established. The situation is comparable to the recent recognition of two other new monocot families, Anemarrhenaceae and Behniaceae (Conran et al. 1997), based in part on relationships (or lack of close relationship) suggested by molecular sequence data. Since the Hopkinsiaceae and Lyginiaceae were not recognised by Kubitzki (1998), information is provided here covering aspects treated for other monocot families in the Families and Genera of Flowering Plants vol. 4. 


\section{Key to families of Poales}

Restionaceae and allied families are generally included in the order Poales, but the circumscription of that order has varied in different classifications. The Angiosperm Phylogeny Group (APG 1998) included 15 families in Poales. The following key, however, covers only the more restricted circumscription of seven families by Dahlgren et al. (1985), together with the two new families now described. This range includes the families considered to be closest relatives of the Restionaceae and of the members of the Anarthria clade.

1 Anthers 2-sporangiate, not lobed, with 1 dehiscence slit 2

1* Anthers 4-sporangiate, 2-lobed, opening by 2 longitudinal slits

2 Flowers mostly with tepals; male flowers with 2-3 stamens, females with 1-3 carpels; pollen endexine present Restionaceae

$2^{*}$ Flowers naked; males consisting of a single stamen; females of one carpel; pollen endexine lacking

Centrolepidaceae

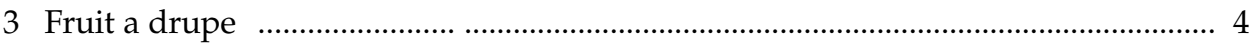

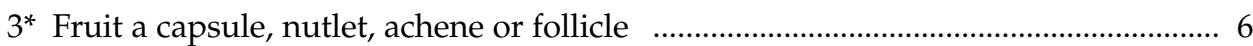

4 Leaf sheaths closed; leaf blades larger than sheaths and ending in a tendril

Flagellariaceae

$4^{*}$ Leaf sheaths open; leaf blades larger or smaller than sheaths and not ending in a tendril

5 Stems terete, without scabrid margins, unbranched below the inflorescence; leaf blades plicate, larger than sheaths; plants with hermaphrodite flowers; ovary trilocular; stylar branches or sessile stigmatic areas 3; stigmas covered with short papillae

Joinvilleaceae

$5^{*}$ Stems flattened, with scabrid margins, repeatedly branched; leaf blades not folded, smaller than sheaths; plants dioecious; ovary unilocular; style single; stigmas covered with long stigmatic branches that are themselves branched Hopkinsiaceae

6 Flowers bisexual, each with a 2-keeled bract (palea) opposite the subtending bract (lemma). Tepals ('lodicules') in one whorl (3 or fewer) Poaceae

$6^{*}$ Flowers unisexual, with 1 or more bracts; bracts not as above (not 2-keeled). Tepals in two whorls (mostly $3+3$ or $2+2$ )

7 Monoecious with male and female flowers together in the same spikelet; stamens 4 or 6; culms striate with deep narrow crypts between broad sclerenchyma-capped ridges

Ecdeiocoleaceae

7* Dioecious; stamens 3; culms not striate or with striations formed by narrow ridges of sclerenchyma not by deep crypts

8 Leaf blades elongated, equitant (as if folded longitudinally with the 2 inner surfaces fused, so that the abaxial margin represents the leaf keel and the blade is vertically orientated); culms striate; stamen filaments not fused into a column

Anarthriaceae

$8^{*}$ Leaf blades of adult plants reduced to an awn at the apex of the sheathing base, not equitant; culms not striate; stamen filaments fused into a column

Lyginiaceae 


\title{
Description of Hopkinsiaceae and revision of Hopkinsia
}

\author{
Hopkinsiaceae B.G. Briggs \& L.A.S. Johnson, fam. nov.
}

Herbae dioeciae, perennes, rhizomatosae; culmi compressi, marginibus scabris; folia dorsiventralia, reducta, vaginiformia; flores tepalis 6, scariosis; flores masculini staminibus 3; antherae bilobatae, dorsifixae, sporangiis 4 , utroque lobo per rimam longitudinalem dehiscentes; filamenta antherarum discreta; grana pollinium aperturis angustis; flores feminei ovario uniloculari et stylo unico; ovulum unicum; fructus parva drupa.

Type and only genus: Hopkinsia W. Fitzg.

Perennial, glabrous, dioecious herbs with sympodial growth of rhizomes and culms; caespitose with short rhizomes and forming large dense tussocks, or with long rhizomes and forming diffuse patches of widely separated culms. Rhizomes covered by appressed scales. Culms branched, smooth and terete near the base, becoming flattened and concavo-convex above, with scabrous lateral margins. Leaves not caducous, consisting of a sheath with a linear reduced lamina; sheath split to the base, scarious, margins membranous; auricles scarious or membranous. Inflorescence bracts: lower ones similar to culm sheaths but smaller, the uppermost hyaline. Flowers wind-pollinated, not in spikelets, each in the axil of a membranous bract, not dorsiventrally or laterally compressed; perianth of 6 membranous tepals in two whorls. Male flowers: stamens 3, opposite the inner tepals; filaments free; anthers dorsifixed, exserted, apically notched, 2-lobed, 4-thecate, latrorse, each lobe apiculate and dehiscing by a longitudinal slit; the lobes attached below the midpoint to the connective which is c. $1 / 5$ as long as anther; spirally twisted after dehiscence; pistillode absent. Female flowers lacking staminodes; ovary superior, shortly stipitate, 1-locular, not angled; the style single, stout, densely covered adaxially (except for a narrow adaxial groove, i.e. stigma double-crested) by long stigmatic branches that are branched and papillose, style attachment slightly excentric; the ovule solitary, pendulous, orthotropous, bitegmic and tenuinucellate. Fruit a globose or elliptic small drupe with a thin fleshy outer pericarp and a hard inner pericarp (although indehiscent the slightly thickened and pale carpel margins are discernible and readily separable on dissection); shed with a short fleshy pedicel and bracts and perianth attached.

Vegetative structure and anatomy: the culms are the main photosynthetic organs of the plants and resemble those of Restionaceae in general structure (Cutler 1969; Gilg-Benedict 1930; Cheadle \& Kosaki 1975; Pate \& Meney 1999; Meney, Pate \& Hickman 1999). The culm epidermis is tanniniferous and heavily thickened on the outer wall; stomates are sunken, overarched by cuticular projections of epidermal cells; substomatal cavities extend deeply into the chlorenchyma. The chlorenchyma consists of 3-4 layers of short palisade cells with little or no development of pegs; pillar cells, protective cells and sclerenchyma girders are absent. To the inside of the chlorenchyma is a parenchyma sheath, 1(-2) cells thick, surrounding the strongly developed sclerenchyma cylinder. The outer vascular bundles are small and embedded in the sclerenchyma, the inner bundles are larger with narrow sclerenchyma sheaths. The central tissue is parenchymatous with patches of thinwalled cells but no central cavity. Silica is apparently absent. The roots are sandbinding with a dense covering of persistent root hairs. The anatomy of rhizomes and roots is illustrated by Meney, Pate and Hickman (1999).

Inflorescence and flower structure: inflorescences are (in the terminology of Briggs \& Johnson 1979) blastotelic (not terminated by a flower) and anauxotelic (axes not growing on after flowering) as described for Restionaceae by Kircher (1986). 
The arrangement of axes, especially after flowers have fallen, may suggest sympodial growth but we interpret the inflorescence structures as not sympodial. Flowers are not in spikelets; flowers or flower-clusters are in the axils of small, ovate, acute, hyaline bracts at two or several closely-spaced uppermost nodes of the culms and the lateral branches. Male inflorescences bear clusters of several flowers on short slender axes; female inflorescences are similar but bear a single flower in such a position. Both male and female inflorescences are terminated by very small abortive axes (at the base of the uppermost flower) bearing minute bracts. Male and female flowers are described above for the family.

Pollen and embryology: the pollen grains are spheroidal to oblate, ulcerate, with a polar diameter of 24-28(-33) $\mu \mathrm{m}$. (Chanda 1966; Ladd 1977). The pollen walls show a well-developed foot-layer, columellate interstitium, and a well developed tectum, with numerous pores ('scrobiculi') penetrating the tectum and the foot-layer, as well as other pores ('puncta') that penetrate the tectum only. The pollen surface shows micro-verrucate ornamentation. The aperture is of graminoid type (Linder \& Ferguson 1985), the annulus with a heavily thickened foot-layer, and the aperture diameter less than 3-4 $\mu \mathrm{m}$. A thin layer of endexine covers the ulcus and extends some distance under the margins. The endothecium of the anthers contains spiral thickenings that are distinctive in forming perfect helices that are doubled (Manning \& Linder 1990). The integuments are impregnated with tannins and the nucellar epidermis consists of isodiametric cells (Kellogg \& Linder 1995); the small, densely packed cortical cells of the ovary resemble those of Lyginia (Linder 1992). The stigmas are dry. Embryo development has not been studied.

Karyology: only a count of $2 n=18$ for $H$. adscendens, here published, is available. (Fig. 3).

Fruit, seed and reproductive biology: flowers are wind-pollinated; the pollen is released explosively and is normally completely expelled from the anther. The dispersal unit is the fruit; a small drupe with thin fleshy pericarp, shed with a short stout fleshy pedicel that contains oil and presumably functions as an elaeiosome. The testa is fused to the pericarp, but with a white layer that may be equivalent to the seed coat of related groups such as Lyginiaceae. Germination is hypogeal with the

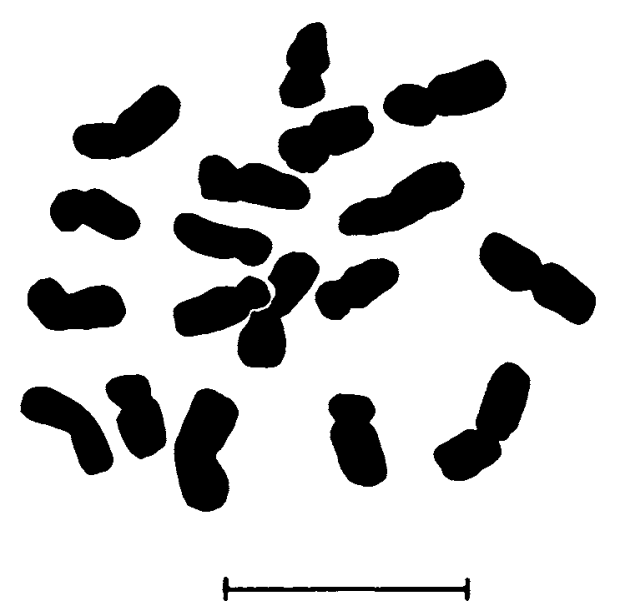

Fig. 3. Hopkinsia adscendens, mitotic metaphase, $2 n=18$ (prepared as in Briggs 1966); voucher: Briggs 358. Scale bar $=5 \mu \mathrm{m}$. 
epicotylar rhizome developed (Pate \& Meney pers. comm.; Pate \& Meney 1999). The rhizomatous habit facilitates resprouting after fire and, with the sand-binding roots, serves to anchor these floodplain species which are subject to wash-aways of the sandy substrate.

Phytochemistry: Hopkinsiaceae resemble some Restionaceae (Lepyrodia and Sporadanthus) in having a simple flavonol pattern but lack flavones (Williams et al. 1997). Quercetin and isorhamnetin are reported in both Hopkinsia species; proanthocyanidins and flavonoid sulphates are absent.

Distribution: one genus of two rare species on deep, seasonally moist, sandy soils, that are oligotrophic or somewhat saline, in the southern half of Western Australia, mostly near watercourses in regions of rather low rainfall.

Systematics and relationships: since the first description of species of Hopkinsia, this has been included in Restionaceae. As mentioned above, DNA sequencing of the chloroplast genes (Briggs et al. 2000) has now given convincing evidence that Hopkinsia is more closely related to Anarthriaceae than to Restionaceae.

Hopkinsiaceae possess various features considered plesiomorphic within Poales: the inflorescence with flowers not in spikelets, flowers with tepals not reduced in number, tetrasporangiate anthers, graminoid pollen, presence of flavonoids but absence of flavones. They differ from Restionaceae in the distinctive wiry, branching culms and have a unique combination of features of culm anatomy (lacking pillars, girders and protective cells; chlorenchyma of 3-4 layers of cells; silica absent). They share with Lyginiaceae, and with various other Poalean families, many features considered primitive in the Poales. Similarities to Lyginiaceae include the conspicuous sandbinding root-sheath of persistent, lignified, long root hairs (Pate \& Meney 1999) and the stout styles with stigmatic branches (Linder 1992), but they differ markedly in habit, vegetative and floral morphology, fruits and seeds. They have none of the highly distinctive features of the leaves and culm anatomy of Anarthriaceae or of Ecdeiocoleaceae.

\section{Hopkinsia}

Hopkinsia W. Fitzg., J. Western Australia Nat. Hist. Soc. 1: 33 (1904).

Type species: H. anoectocolea (F. Muell.) D.F. Cutler

Description and distribution: as for the family.

\section{Key to species}

1 Caespitose, forming large many-stemmed tussocks; rhizomes stout, 5-9 mm diam.; culms 35-100 cm tall, densely crowded on the rhizomes; culm internodes (3-)6-11 cm long; culm sheaths 2.5-3.5 cm long; 2-4 inflorescence branches arising at each upper node

1. H. anoectocolea

$1^{*}$ Not caespitose; culms few and widely separated, arising from elongated horizontal or ascending rhizomes; rhizomes slender, 1.2-2.5 mm diam.; culms $15-50 \mathrm{~cm}$ tall; culm internodes $1.5-7 \mathrm{~cm}$ long; culm sheath $0.7-1.5 \mathrm{~cm}$ long; inflorescence branches arising singly at upper nodes 
1. Hopkinsia anoectocolea (F. Muell.) D.F. Cutler, Kew Bull. 21: 61 (1967).

Basionym: Lepyrodia anoectocolea F. Muell., Fragm. 8: 78 (1873).

Type: Western Australia: W.A., J. Dr [Drummond] ô (lecto, here selected MEL 14642; iso MEL 14640-1, 14643, 15097, B, BM, K, P). [Some isotypes may be $q$ : such plants are difficult to distinguish from $\hat{\sigma}$ when fruits have fallen.]

Anarthria calovaginata Gilg in Engl., Bot. Jahrb. Syst. 35: 87 (April 1904). Hopkinsia calovaginata (Gilg) Gilg-Ben., Nat. Pflanzenfam. 2, 15a: 17 (1930).

Type: in distr. Avon pr. Tammin ... D[iels] 5090 ô, 25 Oct 1901 (iso PERTH).

Hopkinsia scabrida W. Fitzg., J. Western Australia Nat. Hist. Soc. 1: 35 (May 1904).

Type: Cunderdin, saline spots, W.V. Fitzgerald, Nov 1903 ơ $q$ (syn PERTH 2067137, 1050109; isosyn B, NSW 406892, 413034).

Caespitose, forming large tussocks, sometimes to $1 \mathrm{~m}$ diam. Rhizomes horizontal, up to $30 \mathrm{~cm}$ long or more, 5-9 mm diam., nodes 3-8 $\mathrm{mm}$ apart, bearing crowded culms with their bases contiguous; covered with short glossy brown scales $5-8 \mathrm{~mm}$ long. Culms 35-100 cm tall, 0.5-2 mm diam.; internodes (3-)6-11 cm long; young culms pink, turning blue-green; old culms grey-green, glaucous, rigid and wiry; branching except at the lowest nodes, with (1-)2-4 lateral branches at each node; base with several erect scales $1.5-6 \mathrm{~cm}$ long. Culm sheaths lax, sometimes recurved, reddish brown, oblong, broadest near the middle, $2.5-3.5 \mathrm{~cm}$ long; auricles scarious; lamina 2-15 mm long. Inflorescence branches 2-4 at each upper culm node, flowers shortly pedicellate, in clusters of 4-18 toward the apex of branches, subtended by broaddeltoid, acute, hyaline bracts; outer bract c. $3 \mathrm{~mm}$ long, inner bract c. $1.5 \mathrm{~mm}$ long. Male flowers: tepals ovate, concave, reddish or yellowish brown, soft, hyaline, acute; outer tepals 1.3-1.9 mm long; inner tepals 2-2.6 mm long. Female flowers: tepals similar to males, \pm equal, $2.5-3 \mathrm{~mm}$ long. Fruit $2.2-2.7 \mathrm{~mm}$ long, $1.8-2.5 \mathrm{~mm}$ wide, red when young, aging to brown, on a stout pedicel; seed surface patterned with convex isodiametric angular cells.

Distribution: occurs in Western Australia north of Perth, at and near the Arrowsmith River and eastwards at sites from the Mortlock River to Mekering and Tammin. In flood-beds of watercourses, on deep sands or saline and clayey sands. Regenerates after fire or flood by resprouting.

Conservation status: vulnerable (CALM code P2), with widely separated small populations, sometimes locally abundant but occurring in habitats of limited occurrence in regions of much clearing of natural vegetation and salinisation (Meney, Pate, Dixon, Briggs, \& Johnson 1999).

Selected specimens examined: Western Australia: Irwin: Arrowsmith Lake, George 12931, 9 Dec 1974 of, o (PERTH); Drummonds crossing, Brand Hwy at Arrowsmith River, Briggs 6406 o , 6410 + , 27 Sep 1976 (NSW, AD, CANB, K, MEL, PERTH), Briggs 8618, Johnson, Meney, Linder E Pate, 8 Sep 1990 o (NSW, BOL); 36 km NNW of Eneabba, Briggs 9366 ơ, 9367 \& \& Pate, 6 Oct 1995 (NSW, NBG, PERTH). Avon: 3 km E of Meckering, Wilson 6413, 11 Nov 1968 (PERTH, K, NSW); Waeel, Mortlock River, Wilson 6395, 23 Nov 1967 ơ (PERTH, K, NSW); c. 18 km WNW of Cunderdin, Haegi 1164, 3 Oct 1976 (PERTH); 6.5 miles [11 km] E of Cunderdin, 0.5 miles [1 km] E of 103 mile peg, Briggs 202 đ, 203 ㅇ, 5 Sep 1966 (NSW, CANB, K, MEL, PERTH); 86-87 mile peg, E of Meckering, Gardner, 14 Dec 1945 o, + (PERTH).

2. Hopkinsia adscendens B.G. Briggs E L.A.S. Johnson, sp. nov.

A $H$. anoectocolea combinatione characterum sequentium distinguitur: rhizomata angusta; culmi $15-50 \mathrm{~cm}$ longi, distantes vel aliquot aggregati; internodia brevia, $1.5-7 \mathrm{~cm}$ longa; vaginae culmorum breves, $0.7-1.5 \mathrm{~cm}$ longae; ramuli inflorescentiorum singulatim in quoque nodo superiore. 
Type: Western Australia: Oldfield R., $61.7 \mathrm{~km}$ E of Ravensthorpe, $0.5 \mathrm{~km} \mathrm{~N}$ of bridge on Hassell Hwy, B. Briggs 9343, J. Pate E K. Meney, 3 Oct 1995 q (holo NSW; iso MO, NBG, PERTH).

Forming diffuse patches of widely separated culms arising singly or several together from long slender horizontal or ascending rhizomes which are up to at least $30 \mathrm{~cm}$ long, $1.2-2.5 \mathrm{~mm}$ diam, internodes $1-3 \mathrm{~cm}$ long. Culms $15-50 \mathrm{~cm}$ tall, $0.8-1.5 \mathrm{~mm}$ diam.; internodes $1.5-7 \mathrm{~cm}$ long; young culms pink, turning blue-green; old culms grey-green, glaucous, rigid and wiry, branched from near base, a single lateral branch per node. Sheaths erect, oblong-spathulate, broadest toward the apex, slightly lax, scarious, red-brown, $0.7-1.5 \mathrm{~cm}$ long, truncate, auriculate; lamina $0.5-3 \mathrm{~mm}$ long. Inflorescence branches singly at upper nodes; flowers in clusters of 2-4 at the apex of inflorescence branches, subtended by broad-deltoid, hyaline bracts almost as long as the flowers. Male and female flowers 1.5-3 mm long, outer tepals 1.6-2.0 mm long, inner tepals 2.0-2.6 mm long. Fruit ovoid, c. $2.7 \mathrm{~mm}$ long. Chromosome number: $2 n=18$ (Briggs unpublished, voucher Briggs 358). (Fig. 4.)

The epithet is from the Latin adscendens, ascending, referring to the rhizomes.

Distribution: occurs in Western Australia in a few locations from Chillinup (NE of Albany) to the Esperance district. Grows in heath on sand or peaty sand in the floodplain of watercourses in a region of moderately low rainfall, often with eucalypts, Banksia and Nuytsia. The occurrence of male and female plants suggests that individual clones may be as large as $200 \mathrm{~m}$ across. Regenerates after fire by resprouting.

Conservation status: endangered (CALM code R), limited to an uncommon habitat type and occurring in regions of much clearing of natural vegetation and salinisation (Meney, Pate, Dixon, Briggs \& Johnson 1999; Pate 2000). Listed as at some risk but poorly known (code 3K) by Briggs and Leigh (1996), but this appears to understate the threats to this species.

Specimens examined: Western Australia: Eyre: $9 \mathrm{~km}$ E of Chillinup Homestead, Newbey 4882, Oct 1975 (PERTH); Oldfield R. (details as for type), Briggs 9342 et al. ô (NSW, MO, NBG); c. 18 km NNW of Young River crossing on Ravensthorpe -Esperance main road, Jackson 1437, 16 Oct 1968 ô (AD, NSW); Lort River, c. $65 \mathrm{~km} \mathrm{~W}$ of Esperance, Orchard 1472, 11 Oct 1968 ô (AD, NSW, PERTH); Lort R., Esperance -Ravensthorpe Rd, Briggs 426, 11 Sep 1966 o (NSW, PERTH), Meney 393, 5 Mar 1993 ô (NSW); 40 miles [67 km] W of Esperance on Ravensthorpe road, Briggs 420, 11 Sep 1966 ㅇ (NSW, K, PERTH), 421 o (NSW, PERTH); 18 km NNW of Young R. crossing on Ravensthorpe-Esperance Rd, Jackson 1437, 16 Oct 1968 ơ (PERTH, K, NSW); c. 10 miles [16 km] E of Esperance on Cape Le Grand road, c. 1.5 miles [3 km] W of Cape Le Grand turn-off, Briggs 358, 9 Sep 1966 ơ (NSW, MEL), 358a (NSW).

\section{Description of Lyginiaceae and revision of Lyginia}

Lyginiaceae B.G. Briggs \& L.A.S. Johnson, fam. nov.

Herbae dioeciae, perennes, rhizomatosae vel caespitosae; culmi teretes; folia dorsiventralia, reducta, vaginiformi; flores tepalis 6; flores masculi staminibus 3; antherae bilobatae, dorsifixae, sporangiis 4, utroque lobo per rimam longitudinalem dehiscentes; filamenta antherarum connata; grana pollinium aperturis angustis; flores feminei ovario triloculari; ovulum unicum in quoque loculo; stylus crassus, in dimidio superiore 3-partitus; fructus capsularis, triloculatus, loculicidus; semina alba, spiculis minutis et crista mediana ornata.

Type and only genus: Lyginia $\mathrm{R}$. Br. 

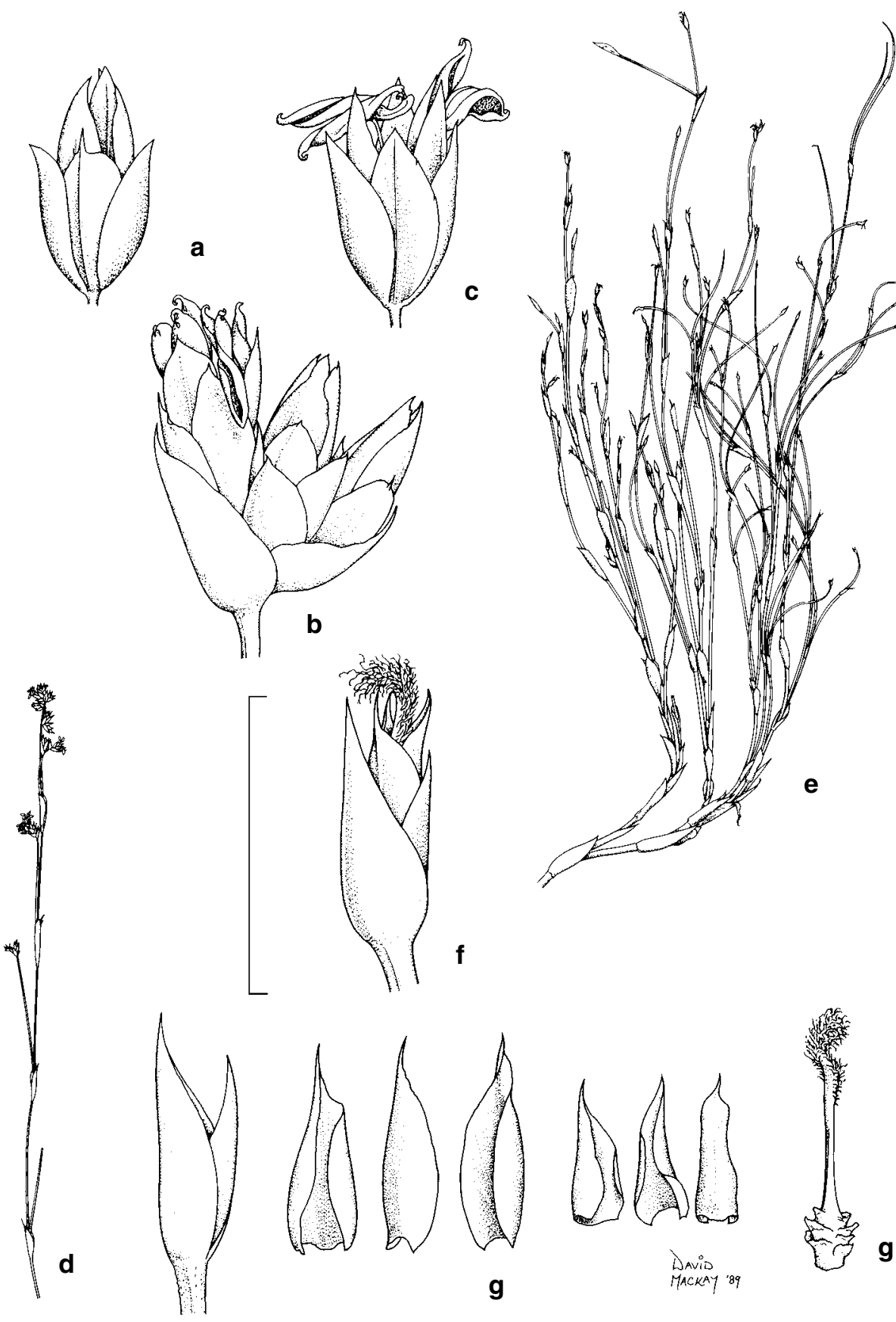

Fig. 4. Hopkinsia adscendens. a-d, male: $\mathbf{a}$, flower bud with bracts; $\mathbf{b}$, flower cluster; $\mathbf{c}$, flower; $\mathbf{d}$, inflorescence (Briggs 421). $\mathbf{e}-\mathbf{g}$, female: e, habit; f, flower; $\mathbf{g}$, dissected flower with bracts, 6 tepals and gynoecium (Briggs 420). Scale bar: a, b, c, f, g = $4 \mathrm{~mm}$; $\mathrm{d}, \mathrm{e}=6.7 \mathrm{~cm}$. 
Perennial, rushlike, dioecious herbs with sympodial growth of rhizomes and culms, glabrous apart from cilia often on margins of culm and rhizome sheaths, spathes and glumes; caespitose with short or erect rhizomes and forming small or large, dense or \pm open tussocks, or with long creeping rhizomes and forming diffuse patches of widely separated culms. Rhizomes covered by appressed, overlapping scales. Culms unbranched, terete, smooth or finely rugose, with several nodes. Leaves reduced to appressed sheaths, split to the base, persistent, rigid, acuminate; with a rigid, usually black, incurved awn representing the reduced, dorsiventral lamina. Flowers not in spikelets, singly or on short branching lateral axes in the axils of spathes at one or several, usually closely spaced, uppermost culm nodes; wind pollinated, shortly pedicellate, subtended by a bract; spathes persistent, rigid, acute or acuminate, mostly partially obscuring the flowers; perianth of 6 tepals in two whorls, glabrous or ciliate at the tips. Male flowers subtended by a hyaline bract as long as the tepals; dorsiventrally compressed; tepals hyaline, blunt or acute or acuminate, glabrous or ciliate at apex; outer lateral tepals keeled and the other outer and three inner tepals \pm flat; stamens 3, opposite the inner tepals; filaments connate into a stout tapering solid column; anthers tetrasporangiate, free, dorsifixed, exserted, extrorse, attached below the midpoint to the top of the column, apically notched, 2-lobed, often twisted after anthesis; connective c. 1/3 anther length; each lobe apiculate and dehiscing by a longitudinal slit; pistillode absent. Female flowers not dorsiventrally or laterally compressed, shortly pedicellate; tepals rigid, acute or acuminate, not keeled, the margins toward the base hyaline, inner tepals shorter than outer; staminodes absent; ovary superior, 3-locular, 3-angled; style branches 3, fused in the lower third or half, stout, densely covered (except for a narrow adaxial groove [i.e., stigma doublecrested] and an abaxial ridge) by stigmatic papillae that are papillose; stigmas dry; ovules solitary in each loculus, placentation axile, pendulous from summit of loculus, orthotropous, bitegmic, tenuinucellate. Fruit a woody, 3-locular, 3-angled, loculicidal capsule, style base persistent as a beak. Seeds globose, flattened near the hilum, encircled in the median vertical plane by a hyaline flange; the outer layer white, readily detached; the surface with fine short spines or hooks arising from the corners of minute concavities.

Vegetative structure and anatomy: Lyginiaceae are evergreen, rush-like plants but the species differ in growth habit and regenerative response. Two are caespitose but one has extensive rhizomes producing patches of widely spaced culms; one is an obligate seeder but two are resprouters (Bell \& Pate 1993; Meney, Pate \& Hickman 1999). Growth is sympodial, the rhizomes covered by dark brown, usually glossy scales. The sheaths surrounding the base of the culms develop a pattern of transverse cracks. The culms are the main photosynthetic organs of the plants and are lime-green, yellowing with age. The leaves are reduced to sheaths, which are persistent and conspicuously or minutely ciliate or glabrous; with a stout tapering awn representing the reduced lamina, or with some development of the lamina in juvenile plants and in regrowth after fire. The roots are stout and sand-binding, and may attain great length with a dense covering of persistent root-hairs; penetration to $4 \mathrm{~m}$ depth is reported by Pate and Meney (1999). The cilia on sheaths, spathes, bracts and tepals are stout, tapering, multicellular, multiseriate, shortly papillate but unbranched.

The culms of the Lyginiaceae resemble those of Restionaceae in their specialisation for the combined functions of mechanical strength, photosynthesis, and resistance to damage due to desiccation (Cutler 1969; Gilg 1891; Gilg-Benedict 1930; Malmanche 1919; Cheadle 1955; Cheadle \& Kosakai 1975). The stomates are oblique, sunken, overarched by the radially-elongated epidermal cells. Under the epidermis is the 2-layered chlorenchyma of palisade-like cells, with peg-cells in the substomatal regions, interspersed with areas of thick-walled non-photosynthetic cells (not bordering substomatal cavities); pillar and protective cells of the types found in 
various Restionaceae and sclerenchyma girders are all absent. (Cutler [1969, Fig. 35] identifies thick-walled cells in the chlorenchyma of Lyginia as pillar cells, but notes [p. 234] that 'They are derived from palisade chlorenchyma cells [rather than cells of the parenchyma sheath] and therefore cannot be regarded as true pillar cells.') To the inside of the chlorenchyma is the parenchyma sheath, 1(-2) cells thick surrounding the sclerenchyma cylinder. The outer vascular bundles are embedded in the sclerenchyma cylinder, the inner bundles are scattered in the pith. Some pith cells include slabshaped crystals; there is no central cavity. The central ground tissue is sclerenchymatous around the lignified bundle sheaths, and there are numerous intercellular spaces. The anatomy of rhizomes and roots is illustrated by Meney, Pate and Hickman (1999) and further description of morphology and anatomy given by Pate and Meney (1999) and Pate and Delfs (1999).

Lyginia shows several distinctive anatomical features (Gilg 1891; Cutler 1969): the thinwalled cells lining the substomatal cavity which are unlike those of genera in related families that show differentiated substomatal cells, the oblique epidermal cells, stomata at an angle to the epidermal cells, and slab-shaped crystals in some cells of the central ground tissue. The absence of silica also contrasts with the usual condition in Restionaceae. Cheadle (1955) considered the vessels of the shoot system (but not of the roots) of Lyginia to show especially primitive characteristics.

Inflorescence and flower structure: inflorescences are blastotelic (not terminated by a flower [Briggs \& Johnson 1979]) and anauxotelic (axes not growing on after flowering); with rigid, acuminate culm spathes at 1-several uppermost culm nodes, subtending short flowering branches that may bear smaller spathes subtending very short flowering branches; each flower subtended by a glume-like bract. Female inflorescences are fewer-flowered and less branched than the males. Male and female flowers are described above for the family.

Pollen morphology and embryology: the single pollen grains are spheroidal to oblate, c. 30-38 um polar diameter (Chanda 1966; Ladd 1977). The pollen walls show a footlayer, columellate interstitium, and a thin tectum, with numerous pores penetrating the tectum and the foot-layer ('scrobiculi'), as well as pores ('puncta') that penetrate the tectum only. The pollen surface has micro-verrucate ornamentation. The annulus consists of a heavily thickened foot-layer, and the aperture is of 'graminoid' type (Linder \& Ferguson 1985) with a diameter about $7 \mu \mathrm{m}$. A thin layer of endexine covers the ulcus and extends some distance under the margins. The endothecium of the anthers contains spiral thickenings but these often form U-shapes rather than complete helices, showing similarity to the condition in Anarthriaceae (Manning \& Linder 1990). The ovary walls are impregnated with tannins. Linder (1992) observed that the ovary is similar to that of Anarthria but has small densely packed cortical cells more like those of Hopkinsia. The orthotropous, tenuinucellate ovules are bitegmic, with the inner integument tanniniferous. Megagametophyte development is not known beyond the 8-nucleate stage but there are three antipodals and large starch grains in the mature megagametophyte (Rudall \& Linder 1988). The development of the embryo has not been studied.

Karyology: Lyginiaceae have the number of $n=6$ (Johnson \& Briggs 1981; Bell \& Pate 1993) which is not known in the Restionaceae and the chromosomes are larger than in the latter family, although not as large as in Anarthriaceae (Briggs 1966). [Johnson and Briggs (1981) corrected a previous erroneous count by Briggs (1966)]. Bell and Pate studied all species and observed that there 'were no apparent differences in size or configuration of chromosomes among [them]'.

Fruit and seed: the capsule develops from a 3-locular ovary, with one seed per locule. The seed has a readily detached, white outer layer. The surface is highly distinctive 
with cuticular spinules arising from the angles of palisade-like, very slender and radially elongated cells of the outer layer of the testa; the cuticle is concave over the outer surface of each cell. The flange encircling the seed in the median vertical plane appears to be a projection of the cuticle and not a cellular structure.

Reproductive biology: the flowers are wind-pollinated and dioecious, with the seeds serving as disseminules. The pollen is released explosively and normally completely expelled from the anther. Flowering is autumn or spring (bimodal) (Meney \& Pate 1999). Germination is hypogeal with the epicotylar rhizome developed (Pate \& Meney pers. comm.) Lyginiaceae occur in fire-prone environments, and the presence of an obligate seeder species as well as resprouters, with distinctive patterns of resource allocation, was reported and discussed by Pate and colleagues (Bell \& Pate 1993; Meney, Dixon \& Pate 1999; Pate, Meney, Dixon, Bell \& Hickman 1999).

Fungal associates: Lyginiaceae resemble Restionaceae in their resistance to Phytophthora infection but a culm smut recorded as infecting all Lyginia species (Websdane et al. 1994; Sieler et al. 1999) is sufficiently distinctive to have been described as the new monotypic genus Websdanea (Vánky 1997). This smut has not been recorded on other hosts. Meney et al. (1993) recorded the presence of mycorrhizal associations for a brief period during winter in the roots of Lyginia; mycorrhizae have rarely been reported in Restionaceae.

Phytochemistry: Lyginia differs from members of related families in the presence of the unusual sugar allose and of allosides, while resembling Restionaceae in producing some simple flavonol glycosides (Williams et al. 1997). Quercetin and isorhamnetin were reported in most samples; proanthocyanidins and flavonoid sulphates are absent. Williams et al. also note that, as in some Restionaceae, 'the more chemically advanced 8-hydroxyflavonol gossypetin ... is present in at least one species'. Unlike Restionaceae, Lyginia produces significant amounts of fructan-type oligosaccharides in its rhizomes and lacks starch (Pate, Meney \& Dixon 1991).

Systematics and relationships: Lyginia has until now been included in Restionaceae. As noted above, cladistic analysis of DNA sequence data from the chloroplast gene $r b c \mathrm{~L}$, the $\operatorname{trn} \mathrm{L}$ intron and the $t r n \mathrm{~L}-\mathrm{F}$ intergenic spacer (Briggs et al. 2000) do not associate Hopkinsia and Lyginia with Restionaceae but show a robust clade of these two genera with Anarthria. Within this clade Anarthria is sister to (Hopkinsia, Lyginia).

As with Hopkinsia, the general similarity of Lyginia to Restionaceae in gross morphology and anatomy, and its occurrence in a region of great diversity of Restionaceae, have led to its distinctiveness being overlooked. Lyginiaceae possess various conditions that are considered plesiomorphic within Poales, in the inflorescence, flowers (unreduced tepals, tetrasporangiate anthers, gynoecium), pollen morphology, ovule and flavonoids. However, they show distinctive apomorphies in inflorescence structure, connate staminal filaments, stomatal position, structure of the chlorenchyma, and seed surface.

Distribution and habitats: the single genus Lyginia is widespread on well drained or seasonally moist oligotrophic soils in the southern half of Western Australia, in regions of moderate to low rainfall. One species is rare but two are wide-ranging and common.

\section{Lyginia}

Lyginia R. Br., Prodr.: 248 (1810).

Lectotype: L. barbata R. Br. (typ. cons.) (In 1910, Lyginia R. Br. was conserved against Schoenodum Labill., following a proposal by Janchen 1908), but this was subsequently recognised as a superfluous conservation (Rickett \& Stafleu 1959, p. 231). Schoenodum 
tenax Labill. was based on specimens of two species. Brown selected the male specimen as lectotype, basing Leptocarpus tenax (Labill.) R. Br. on it, while referring the female syntype to Lyginia imberbis R. Br. Lyginia is no longer included among the nomina conservanda genericorum, although it retains a conserved type.)

Description and distribution: as for the family.

Species within Lyginia have proved difficult to delimit, so that the names L. barbata and L. imberbis have been defined variously, or the whole genus considered to be only a single species. A major clarification came with the studies of Bell and Pate (1993) who investigated the reproduction and regeneration of plants and distinguished five morphotypes. These were characterised by differences in rhizome morphology, culm height and density, spikelet morphology, response to fire, timing of first reproduction in juveniles, and seed/ovule numbers and ratios. The species now recognised equate to these units, as characterised by Bell and Pate, as follows:

L. excelsa sp. nov. = morphotype S: 'tall-culmed, densely tufted fire-sensitive obligate seeder'.

L. imberbis $\mathrm{R}$. Br. = morphotypes $\mathrm{R}_{1:}$ 'tall densely tufted fire-resistant resprouter'; $\mathrm{R}_{2}$ : 'short flexuose-culmed, tufted resprouter'; and $\mathrm{R}_{3}$ : 'weakly clonal, semi-tufted resprouter'.

L. barbata $\mathrm{R}$. Br. = morphotype $\mathrm{R}_{4}$ : 'short-culmed, widely spreading clonal form'.

We have concluded that there is no basis for specific distinctions between morphotypes $R_{1}, R_{2}$ and $R_{3}$. L. imberbis, as now recognised, is by far the most variable and abundant of the species. It includes considerable local variation; for example, plants from different sites often show consistent differences in culm height and sinuosity, corresponding to three of the morphotypes distinguished by Bell and Pate (1993). L. barbata shows an almost equally wide geographic distribution but is restricted to a much narrower habitat range, whereas L. excelsa is known from only a very few sites. Bell and Pate found differences between the morphotypes now included in L. imberbis in seed/ovule ratios and resource allocation to reproduction, but by far the largest differences in these variables correspond to the specific distinctions now recognised. They noted the clear demarcation between the groups now specifically distinguished, regarding $R_{1}, R_{2}$ and $R_{3}$ as together forming 'an intermediate grouping of resprouter forms', distinct from the obligate seeder and extensive clonal types.

The species occur sympatrically or in close proximity without evidence of intergradation (Bell \& Pate 1993). L. excelsa occurs with L. barbata at Cataby. L. imberbis and L. barbata are found together at various localities but are more often parapatric since L. barbata is generally on more sandy and better drained sites. There is little difficulty in identifying most collections that adequately sample the base of the plant. Especially in the Eyre region, however, some plants are difficult to determine since $L$. imberbis shows considerable variation in the denseness of the tussocks, the extent to which culms are supported by short but distinct rhizomes, and in the development of cilia. Elongated rhizomes are a reliable characteristic of L. barbata, although these do not develop until about the fifth year of growth from seed (Bell \& Pate 1993). Since establishment from seed is infrequent in this strongly clonal species, juvenile plants that would be difficult to identify are correspondingly rarely encountered (Pate 2000). 


\section{Key to species}

1 Plants not caespitose, forming patches of widely spaced culms or small groups of culms connected by long rhizomes; culm sheaths and inflorescence spathes ciliate with stiff hairs

L. barbata

$1^{*}$ Plants caespitose, rhizomes erect or shortly horizontal, with crowded culms; culm sheaths and inflorescence spathes glabrous or sparsely or strongly ciliate 2

2 Culms 30-100 cm tall, straight or sinuous, internodes 5-11 cm long; culm sheaths and inflorescence spathes glabrous or sparsely ciliate with hairs $0.5-2 \mathrm{~mm}$ long; bracts at base of culms closely appressed and with an awn-like lamina 2-10 mm long; female inflorescence flowering at 1-5 upper culm nodes; fertile spathes each subtending a single flower

L. imberbis

2* Culms 50-150 cm tall, straight, internodes 14-25 cm long; culm sheaths and inflorescence spathes ciliate with stiff hairs 3-6 mm long; bracts at base of culms \pm flat in the upper half and not closely appressed, with a small mucro or an awn 1-4 $\mathrm{mm}$ long; female inflorescence flowering at 4- 7 upper culm nodes; fertile female spathes each subtending 1-3 flowers

L. excelsa

Lyginia barbata R. Br., Prodr. 248 (1810)

Lyginia barbata var. barbata

Type citation: (M) v.v.

Type: Western Australia: King George III ${ }^{d} S^{d}$ [Sound], R. Brown (Bennett No. 5838), 1802-5 ô, ᄋ (holo BM [annotated by Brown 'Nov genus inter Restionem']; iso BM, E, P).

[Note on typification. At the International Botanical Congress in 1999 a change was accepted in Article 8.1 of the International Code of Botanical Nomenclature to avoid "unnecessary "lectotype designations" narrowing down the type to a single individual or fragment thereof' (Greuter \& Hawkesworth 1999). The definition of a type (Barrie \& Greuter 1999) now emphasises that 'a specimen is a gathering, or part of a gathering, of a single species ... or of multiple small plants'. Discussion at the meeting confirmed the acceptability of male and female plants of the same taxon within a gathering for purposes of typification. Lectotypes are here designated in some instances where what appears to be a single gathering is mounted on more than one sheet and these are not cross-referenced, but no selection of a lectotype is made between $\hat{\sigma}$ and $q$ specimens of the same taxon mounted on a single sheet.]

Rhizomatous, forming large patches of widely separated culms or of groups of several culms, 2-14 cm apart. Rhizomes, horizontal or ascending; 3-6 mm diam. including the covering of dark brown, appressed, usually glossy scales; internodes $0.5-1.3 \mathrm{~mm}$ long. Culms straight and erect or sinuous, smooth or minutely rugose, $30-80 \mathrm{~cm}$ tall, $1.3-2$ mm diam.; with 4-8 internodes, each 5-18 cm long. Sheaths at base of culms \pm truncate, $10-18 \mathrm{~mm}$ long, closely enwrapping the culms, ciliate, with an awn 4-8 $\mathrm{mm}$ long. Culm sheaths 6-15 mm long, green or red-brown, truncate or tapering abruptly at the apex, ciliate at apex with hairs $2.5-6 \mathrm{~mm}$ long, lax toward apex, with a curved, black awn 6-13 mm long. Culm spathes acute, rigid; 6-13 in male inflorescences, 1-4 in female inflorescences, each subtending only a single flower, or culms with several closely spaced spathes but only the uppermost subtending a flower; spathes 4-12 mm long, ciliate with stiff hairs, with a rigid curved awn as long or longer than the spathe. Lateral branches of male inflorescences condensed or extending beyond the culm spathe and with small spathes conspicuous on the lateral branches, to $2.5 \mathrm{~cm}$ long. Male flowers: tepals hyaline, narrow lanceolate, shortly ciliate at apex, acuminate or 

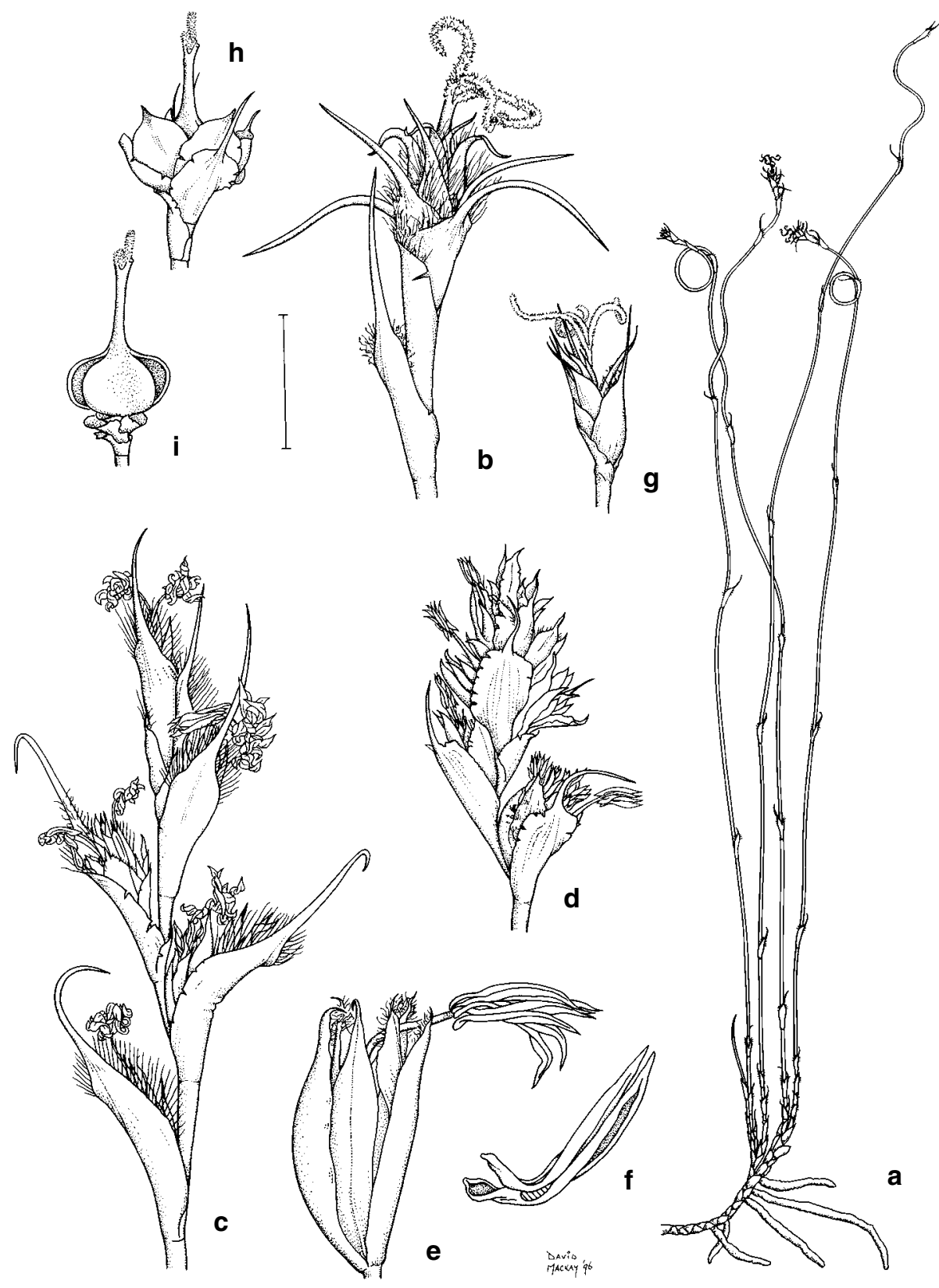

Fig. 5. Lyginia. a-c, L. barbata. a, habit; b, part of female inflorescence (Briggs 6765); c, male inflorescence (Briggs 151). d-i, L. imberbis. d, male inflorescence (Krauss $144 \mathcal{E}$ Howitt); e, f, male flower and dehisced anther (Coveny 8149); g, female flower with bracts (Coveny 8123); h, capsule with bracts and tepals; i, dehisced capsule (Krauss $140 \mathcal{E}$ Howitt). Scale bar: a $=7 \mathrm{~cm}$; b, c, d, g, h, i = $7 \mathrm{~mm}$; e $=3 \mathrm{~mm} ; \mathrm{f}=1.75 \mathrm{~mm}$. 
acute or blunt, 4-6 mm long; filament column 5-7 mm long; anthers 2.5-4 mm long. Female flowers: pedicel c. $1.5 \mathrm{~mm}$ long; tepals rigid, 4-6 $\mathrm{mm}$ long, shortly ciliate toward apex; outer tepals ovate, with a slender black awn 3-5 $\mathrm{mm}$ long; inner tepals narrow deltoid, acute; style 12-15 mm long. Capsule depressed globular, 3-angled, 5-6 $\mathrm{mm}$ long, 6-8 mm diam. Seeds c. $2 \mathrm{~mm}$ diam. Chromosome number $2 n=12$ (Bell \& Pate 1993). (Fig. 5a-c).

Distribution: widespread on oligotrophic soils in the southern half of Western Australia from Eneabba to Israelite Bay, on deep sands in well drained or seasonally damp woodlands and heaths, often with Banksia shrubs. Commonly in better drained habitats than L. imberbis. Regenerates after fire by resprouting. Clones may be long lived and extend over areas 50-100 m across (Bell \& Pate 1993).

Conservation status: widespread and common.

Selected specimens examined: Western Australia: Irwin: $25 \mathrm{~km}$ SSE of Eneabba, Briggs 9007, 8 Oct 1992 ô (NSW); 1 km W of Brand Hwy along Greenhead Road, Wilson 2688, 2 Oct 1979 q (NSW, PERTH); 5 km S of Badgingarra, Keighery 2563, 10 Sep 1979 \& (PERTH); Cataby, Bell \& Pate s.n., Oct 1991 ô, $q$ (KPBG). Darling: c. 29 km NNW of Gingin, Briggs 6765, 11 Oct 1976 ㅇ (NSW); Melaleuca Park, c. 8 km WSW of Bullsbrook, Muir 830, 3 Sep 1977 (PERTH); Bayswater, Gardner, Oct 1940 ㅇ (PERTH); Cannington Swamp, Eichler 15718, 27 Aug 1959 ơ (AD, PERTH); Cannington, Briggs 151, 3 Sep 1966 ô (NSW); W of Yarloop, 3.9 km E of Old Coast Road on Johnsons Road, Hill 4594 o, $4595-6$ ㅇ, 10 Oct 1993 (NSW); 2.4 km SSW of Paynedale along Goodwood Rd, c. 14 km SW of Donnybrook, Briggs 8310 \& Johnson, 25 Oct 1988 오 (NSW); Ambergate, Busselton district, Royce 2869, 18 Oct 1948 \% (PERTH); Bow River, S.W. Jackson, Jan 1913 ô, $q$ (PERTH); 9 km S of Mt Barker, Blake 20879, 1 Sep 1959 ơ (BRI, NSW); Denmark, Gardner s.n., Feb 1940 ô (PERTH); Albany, Preiss 1699, Oct 1840 ơ (NSW). Eyre: below West Mt Barren, ESE of Ongerup, Coveny 3305, 10 Sep 1970 ơ (NSW, CANB, K, NBG, PERTH); 0.8 km S of Gibson, Briggs 335, 9 Sep 1966 ơ (NSW, PERTH, K); Lucky Bay, E of Esperance, Briggs 367 §, 368 ๆ 10 Sep 1966 (NSW, PERTH, RSA).

Lyginia imberbis R. Br., Prodr. 248 (1810)

Lyginia barbata var. imberbis Mast. in A.P.C. de Candolle, Monogr. phan. 1: 303 (1878).

Type citation: (M) v.v.

Type: Western Australia: King George III ${ }^{\mathrm{d}} \mathrm{S}^{\mathrm{d}}$ [Sound], R. Brown (Bennett No. 5837), 1802-5 ㅎ․, ㅇ (holo BM, annotated by Brown 'Restio'; iso BM, E, K, P).

Caespitose, forming small or large, dense or \pm open tussocks. Rhizomes short, horizontal or ascending, with crowded culms, covered by dark brown \pm glossy scales. Culms erect and straight or slightly or strongly sinuous, smooth or minutely rugose, 30-100 cm tall, 0.8-1.4 mm diam.; with 4-6 internodes, each 5-11 cm long. Sheaths at base of culms 5-20 mm long, with a mucro or awn 1-5 mm long, glabrous or sparsely ciliate with hairs c. $1 \mathrm{~mm}$ long, mostly closely enwrapping culms. Culm sheaths 6-18 mm long, green or red-brown, tapering sharply to the apex; glabrous or sparsely ciliate at apex with hairs $0.5-2 \mathrm{~mm}$ long, lax toward apex, with a curved black awn 2-10 mm long. Culm spathes acute, rigid, 1-11 in male inflorescences, 1-5 in female inflorescences, each subtending only a single flower, or culms with several closely spaced spathes but only the uppermost subtending a flower; spathes 3-9 $\mathrm{mm}$ long, glabrous or sparsely ciliate, with a rigid curved awn about as long as the spathe. Lateral branches of male inflorescences condensed and not extending beyond the spathe. Male flowers: tepals hyaline, oblong or narrow lanceolate, glabrous or sparsely ciliate at apex, acuminate or acute or blunt, 5-7 mm long; filament column 7-8 mm long; anthers 2.5-3.5 mm long. Female flowers: pedicel c. $1.5 \mathrm{~mm}$ long; tepals rigid, 3.5-5 mm long, glabrous or sparsely ciliate toward apex; outer tepals ovate, with a slender black awn 2.5-7 mm long; inner tepals deltoid, acute or acuminate; style 8-10 mm long. Capsule depressed globular, 3-angled, 4-5 mm long, 5.5-7 mm diam. Seeds 
c. $2 \mathrm{~mm}$ diam. Chromosome number $2 n=12$ (Johnson \& Briggs 1981, voucher Gittins 1614b; Bell \& Pate 1993). (Fig. 5d-i).

Distribution: widespread on oligotrophic soils in the southern half of Western Australia from the Murchison River to Israelite Bay, in sand or peaty sand in seasonally damp heath and woodland. Commonly in moister habitats than L. barbata. Regenerates after fire by resprouting.

Conservation status: widespread and common.

In addition to the variable features noted by Bell and Pate (1993), plants at the northern end of the geographic range (Murchison River and Kalbarri to just north of Eneabba) show notably slender and straight culms; male plants mostly with numerous (7-11) flowering spathes but females with few (1-2) spathes. Rather similar plants are found elsewhere in the distribution, but the uniformity in this northern region is notable. At Eneabba most plants are very different from those further north, having stout and highly sinuose culms ( type $\mathrm{R}_{2}$ of Bell \& Pate 1993), often with crowded spathes in $\hat{\delta}$ inflorescences.

Selected specimens examined: Western Australia: Irwin: Murchison House Station, Gittins 1614a ô, 1614b $q$, Aug 1967 (NSW); 9 km ENE of Kalbarri, Krauss 140 E Howitt, 16 Apr 1989 q (NSW, MEL, PERTH); 31 km NNW of Eneabba, Krauss 144 \& Howitt, 22 Apr 1989 ô (NSW); 37 km SE of Kalbarri on Ajana road, Wilson 2666, 1 Oct 1979 ơ (NSW, CANB, PERTH, RSA), 2665 ㅇ (NSW, CANB, PERTH); $3.7 \mathrm{~km}$ from Baline on road to Binnu, Briggs 8881 \& Johnson, 13 Aug 1991 \& (NSW); $11 \mathrm{~km}$ E of Dongara on Midlands Road, Briggs 7492 \& Johnson, 30 Sep 1984 \& (NSW, CANB, MEL, PERTH); Eneabba, Bell, Sep 19910 , क (KPBG); Eneabba, Haegi 1928 \& Powell, 1 Sep 1979 (NSW, AD, CANB, K, PERTH, RSA). Darling: White Well Rd, $12 \mathrm{~km}$ due S of Ballidu, Briggs 9000a, 9000b $q$, 7 Oct 1992 ơ, (NSW, PERTH); Kewdale, Coveny 8199, 7 Sep 1976 ơ (NSW, K, PERTH), 8198 q (NSW, BRI, CANB); Brook Rd, Wattle Grove, Coveny 8123, 6 Sep 1976 ㅇ (NSW), 8149 ơ (NSW); South Street, Gosnells, Bell \& Pate, Sep 1991 ô, + (KPBG); W of Yarloop, 3.9 km E of Old Coast Road on Johnsons Road, Hill 4597, 10 Oct 1993 ㅇ (NSW); 2.4 km SSW of Paynedale along Goodwood Rd, c. 14 km SW of Donnybrook, Briggs 8308 E Johnson, 25 Oct 1988 q (NSW); Scott R. Plains, junction of Cane Break Rd and Governor Broome Rd, Briggs 6506, 2 Oct 1976 o (NSW). Avon: 10.5 km E of Cunderdin, Briggs 2000, 5 Sep 1966 ô (NSW); Avon, Pritzel 894 o , 895 $\uparrow$, Nov 1901 (NSW, P); 30.6 km ESE of Pingelly, E side of Tutanning Reserve, Briggs 6655, 6 Oct 1976 q (NSW). Eyre: Oldfield R., 62 km E of Ravensthorpe, Wilson 2820, 13 Oct 1979 đิ (NSW, PERTH); $10 \mathrm{~km}$ WNW of Chillinup Pool, Newbey 4551a ô, 4551b $q, 29$ Oct 1974 (PERTH, NSW); c. 9 km S of Israelite Bay, just W of Lake Daringdella, Green 5104, 21 Nov 1986 + (PERTH). Roe: c. 30 km W of Mt Ragged, Wilson 2935, 10 Sep 1964 ơ (AD, NSW).

Lyginia excelsa B.G. Briggs \& L.A.S. Johnson, sp. nov.

Herbae caespitosae; rhizomata haud producta; seminibus reproductio; vaginae basales 18-40 cm longae; culmi 50-150 cm longi; vaginae culmorum 20-40 cm longae; vaginae culmorum et spathae inflorescentiarum ciliatae, pilis 3-6 mm longis; spathae plantarum feminearum 1-3-floribus.

Type: Western Australia: Brand Hwy N of Cataby, $0.2 \mathrm{~km} \mathrm{~S}$ of Mullering Road, B.G. Briggs 9319, 30 Sep 1995 q (holo NSW; iso CANB, K, PERTH).

Caespitose, forming large, dense tussocks to $30 \mathrm{~cm}$ across at base. Rhizomes short, vertical or steeply ascending, bearing closely crowded culms and dark brown slightly glossy scales. Culms erect, straight, $50-150 \mathrm{~cm}$ tall, $1-2.2 \mathrm{~mm}$ diam, smooth or minutely rugose, with 3-5 internodes each $14-25 \mathrm{~cm}$ long. Sheaths at base of culms, 5-20 mm long, \pm flat in the upper half and not closely enwrapping the culms, with a mucro 1-2 mm long or a short awn to $4 \mathrm{~mm}$ long. Culm sheaths 20-30 mm long, green or brown, tapering gradually toward the apex, ciliate with stiff hairs 3-6 mm long, lax toward apex, with a curved black awn 8-10 mm long. Culm spathes acute, rigid, 7-9 in male inflorescences, 4-7 in female inflorescences; each subtending a short, often 
branched, axis with 1-3 flowers, of which 2 may develop fruit; spathes 10-20 mm long, ciliate with stiff hairs, with a rigid curved awn 6-14 $\mathrm{mm}$ long. Lateral branches of male inflorescences generally extending beyond the spathe, to $15 \mathrm{~mm}$ long. Male flowers: tepals hyaline, linear, sparsely ciliate at apex, acute, 6-7 $\mathrm{mm}$ long; filament column c. $9 \mathrm{~mm}$ long; anthers c. $3.5 \mathrm{~mm}$ long. Female flowers: pedicel 1.5-2.5 mm long; tepals rigid, deltoid, acute, sparsely ciliate toward apex; outer tepals (3-)5-8 mm long, with a slender black awn c. $4 \mathrm{~mm}$ long; inner tepals 5-6 mm long; style 8-10 mm long. Capsule depressed globular, 3-angled, 4-6 mm long, 6-8 mm diam. Seeds c. $2 \mathrm{~mm}$ diam. Chromosome number $2 n=12$ (Bell \& Pate 1993). (Fig. 6).

The epithet is from the Latin excelsus, lofty or high, referring to the stature of the plants, which are mostly taller than other species of Lyginia.

Distribution: occurs in Western Australia north of Perth, at a few sites near Cataby and north of Badgingarra, on sand in dry heath and Banksia woodland.

Conservation status: vulnerable; known from only a few sites and in a region subject to clearing of native vegetation. CALM code P. Obligate seeder species, made more vulnerable since it is killed by even mild fires (Meney, Pate, Dixon, Briggs \& Johnson 1999; Pate 2000).

Specimens examined: Western Australia: Irwin: 2.9 km N of Tootbardie Rd on Hwy 1, Briggs 8921 $\mathcal{E}$ Johnson, 15 Aug 1991 ô (NSW); junction of Brand Hwy and Cooljarloo Rd, N of Cataby, Meney 2191, 22 Oct 1990 q (progeny of this collection, raised from seed: NSW); Brand Hwy N of Cataby (details as for type), Briggs 9317 o (NSW), 9318 \& (NSW, PERTH), 9320 ㅇ (NSW, K, PERTH); Cataby, Bell \& Pate, Oct 1992 \& (KPBG).

\section{Excluded and illegitimate names}

Lyginia tenax (Labill.) Steud. (as Lygynia), Nomencl. bot. ed. 1, 1; 501 (1821) = Leptocarpus tenax (Labill.) R. Br.

Lyginia montevidensis Spreng. in Linn. Syst. veg. 4 (2): 26 (1827). Referred to 'species ignota ... excludenda' by Masters in Candolle Monogr. phan. 1: 303 (1878).

Lyginia symphyonema F. Muell., Fragm. 8: 79 (1873), nom. illeg., based on an inclusive concept of L. barbata R. Br., L. imberbis R. Br. and Schoenodum tenax Labill.

\section{Acknowledgments}

John Pate (University of Western Australia), Kathy Meney, Tina Bell, and Kingsley Dixon (Kings Park and Botanic Garden, Perth) shared their knowledge with us most generously in discussions and in the field. The information they provided helped greatly, especially in clarifying the classification of Lyginia. The DNA studies that provided part of the basis for distinguishing these new families also benefited from plants in tissue culture and seeds provided by Meney and Dixon. Thanks go to colleagues who gave valuable assistance, especially Adam Marchant, Simon Gilmore and Carolyn Porter (whose DNA sequencing studies were crucial to the conclusions reached), Siegfried Krauss and Barbara Wiecek. Horticultural colleagues, at the Mount Annan Botanic Garden and in Sydney, maintained relevant living collections. David Mackay, Nicola Oram and Lesley Elkan were responsible for the illustrations and Peter Wilson assisted with the Latin diagnoses. The opportunity to examine specimens on loan or in other herbaria, and extensive data provided by the Western Australian Herbarium (PERTH), contributed to the study. Grants from the Australian Research Council and Australian Biological Resources Study supported part of the project. Comments on the manuscript from Peter Linder (University of Cape Town) and members of the Telopea Editorial Committee improved the paper. 


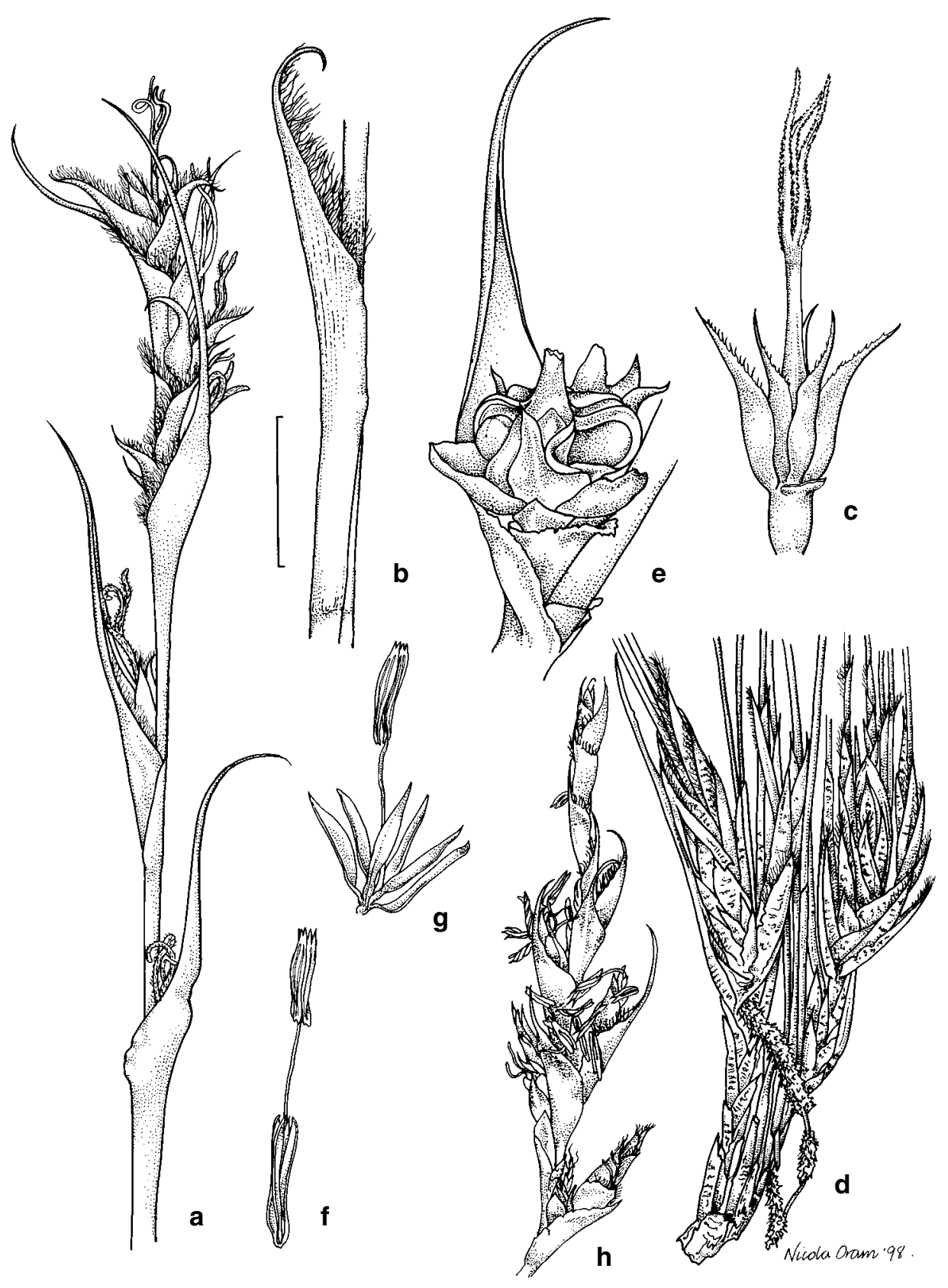

Fig. 6. Lyginia excelsa. a-d, female: a, inflorescence; $\mathbf{b}$, culm sheath; $\mathbf{c}$, flower; $\mathbf{d}$, base of plant with erect rhizomes, sheaths and culm bases (Briggs 9319); e, fruit (Briggs 9320). f-h, male: f, flower; $\mathbf{g}$, flower with tepals opened out; $\mathbf{h}$, inflorescence (Briggs 9317). Scale bar: $\mathrm{a}=1.5 \mathrm{~cm} ; \mathrm{b}, \mathrm{e}=1 \mathrm{~cm}$; c, f, $g=7.5 \mathrm{~mm} ; \mathrm{d}=2.5 \mathrm{~cm} ; \mathrm{h}=3 \mathrm{~cm}$. 


\section{References}

APG (1998) An ordinal classification for the families of flowering plants. Ann. Missouri Bot. Gard. 85: 531-553.

Barrie, F.R. \& Greuter, W. (1999) XVI Intenational botanical Congress: preliminary mail vote and report of Congress action on nomenclatural proposals. Taxon 48: 771-784.

Bayer, R.J. \& Starr, J.R. (1998) Tribal phylogeny of the Asteraceae based on two non-coding chloroplast sequences, the $t r n \mathrm{~L}$ intron and $t r n \mathrm{~L} / \mathrm{trnF}$ intergenic spacer. Ann. Missouri Bot. Gard. 85: 242-256.

Bell, T.L. \& Pate, J.S. (1993) Morphotypic differentiation in the south western Australian restiad Lyginia barbata R. Br. (Restionaceae). Austral. J. Bot. 41: 91-104.

Briggs, B.G. (1966) Chromosome numbers of some Australian monocotyledons. Contr. New South Wales Natl Herb. 4: 24-34.

Briggs, B.G. (2000) What is significant - the Wollemi Pine or the southern rushes? Ann. Missouri Bot. Gard. 87: 72-80.

Briggs, B.G., \& Johnson, L.A.S. (1979) Evolution in the Myrtaceae-evidence from inflorescence structure. Proc. Linn. Soc. New South Wales 102: 157-256.

Briggs, B.G. \& Johnson, L.A.S. (1999) A guide to a new classification of Restionaceae and allied families. Pp. 25-56 in Meney, K.A. \& Pate, J.S. (eds) Australian Rushes, Biology, Identification and Conservation of Restionaceae and allied families. (University of Western Australian Press: Nedlands).

Briggs, B.G., Marchant, A.D., Gilmore, S. \& Porter, C.L. (2000) A molecular phylogeny of Restionaceae and allies. Pp. 661-671 in Wilson, K.L. \& Morrison, D.A. (eds) Monocots Systematics and Evolution (Proc. 2nd Int. Conf. Comparative Biol. Monocots, Sydney 1998). (CSIRO: Melbourne).

Briggs, J.D. \& Leigh, J.H. (1996) Rare or Threatened Australian Plants. (CSIRO: Collingwood).

Chanda, S. (1966) On the pollen morphology of the Centrolepidaceae, Restionaceae and Flagellariaceae, with special reference to taxonomy. Grana Palynol. 6: 355-415.

Cheadle, V.I. (1955) The taxonomic use of specialization of vessels in the metaxylem of Gramineae, Cyperaceae, Juncaceae, and Restionaceae. J. Arnold Arbor. 36: 141-158.

Cheadle, V.I. \& Kosakai, H. (1975) Vessels in Juncales: II. Centrolepidaceae and Restionaceae. Amer. J. Bot. 62: 1017-1026.

Conran, J.G., Chase, M.W. \& Rudall, P.J. (1997) Two new monocotyledon families Anemarrhenaceae and Behniaceae (Lilianae: Asparagales). Kew Bull. 52: 995-999.

Cutler, D. F. (1969) Juncales. In Metcalfe, C.R.(ed), Anatomy of the Monocotyledons, vol. 4. (Clarendon Press, Oxford).

Cutler, D. F. \& Shaw, H.K.A. (1965) Anarthriaceae and Ecdeiocoleaceae; two new monocotyledonous families, separated from the Restionaceae. Kew Bull. 19: 489-499.

Dahlgren, R.M.T., Clifford, H.T. \& Yeo, P.F. (1985) The Families of the Monocotyledons. (SpringerVerlag: Berlin).

Doyle, J. J., Davis, J. I., Soreng, R. J., Garvin, D., \& Anderson, M. J. (1992) Chloroplast DNA inversions and the origin of the grass family (Gramineae). Proc. Natl. Acad. Sci. U.S.A. 89: $7722-7726$.

Gilg, E. (1891) Beiträge zur vergleichenden Anatomie der xerophilen Familie der Restionaceae. Bot. Jahrb. Syst. 13: 541-606.

Gilg-Benedict, C. (1930) Restionaceae. Pp. 8-27 in Engler, A. (ed.), Die Natürlichen Pflanzenfamilien, edn 2, vol. 15a. (Wilhelm Engelmann: Leipzig).

Greuter, W. \& Hawksworth, D. (1999) Synopsis of proposals on botanical nomenclature-St Louis 1999. Taxon 48: 69-128.

Janchen, E. (1908) Zur Nomenklatur der Gattungsnamen. Oesterr. Bot. Z. 58: 466-470.

Johnson, L. A. S. \& Briggs, B. G. (1981) Three old southern families - Myrtaceae, Proteaceae and Restionaceae. Pp. 427-464 in: Keast, A. (ed.) Ecological Biogeography of Australia. (W. Junk: Hague).

Kellogg, E. A. \& Linder, H. P. (1995) Phylogeny of Poales. Pp. 511-542 in: Rudall, P. J., Cribb, P. J., Cutler, D. F., Humphries, C. J. (eds), Monocotyledons: systematics and evolution. (Royal Botanic Gardens: Kew).

Kircher, P. (1986) Untersuchungen zur Blüten- und Infloreszenzmorphologie, Embryologie und Systematik der Restionaceen im Vergleich mit Gramineen und verwandte Familien. Diss. Bot.: 94. (Cramer: Berlin). 
Kubitski, K. (ed.) (1998) The Families and Genera of Flowering Plants, vol. 4. (Springer-Verlag: Berlin).

Ladd, P.G. (1977) Pollen morphology of some members of the Restionaceae and related families, with notes on the fossil record. Grana Palynol. 16: 1-14.

Linder, H.P. (1992) The gynoecia of Australian Restionaceae: morphology, anatomy and systematic implications. Austral. Syst. Bot. 5: 227-245.

Linder, H.P., Briggs, B.G. \& Johnson, L.A.S. (1998) Restionaceae. Pp. 425-445 in, K. Kubitski (ed.) The Families and Genera of Flowering Plants, vol 4. (Springer-Verlag: Berlin).

Linder, H.P., Briggs, B.G. \& Johnson, L.A.S. (2000) Restionaceae - a morphological phylogeny. Pp. 653-660 in Wilson, K.L. \& Morrison, D.A. (eds) Monocots - Systematics and Evolution (Proc. 2nd Int. Conf. Comparative Biol. Monocots, Sydney 1998). (CSIRO: Melbourne).

Linder, H.P. \& Ferguson, I.K. (1985) On the pollen morphology and phylogeny of the Restionales and Poales. Grana Palynol. 24: 65-76.

Linder, H. P. \& Rudall, P. J. (1993) The megagametophyte in Anarthria (Anarthriaceae, Poales) and its implications for the phylogeny of the Poales. Amer. J. Bot. 80: 1455-1464.

Malmanche, L.A. (1919) Contribution à l'étude anatomique des Eriocaulonacées, et des familles voises: Restiacées, Centrolépidacées, Xyridacées, Philydracées, Mayacacées. Thèse Faculté Sci., Paris. Série A, no. 814.

Manning, J.C. \& Linder, H.P. (1990) Cladistic analysis of patterns of endothecial thickenings in the Poales/Restionales. Amer. J. Bot. 77: 196-210.

Meney, K. A., Dixon, K. W. \& Pate, J. S. (1999) Seed reproduction and germination ecology in Restionaceae. Pp. 97-108 in Meney, K. A. \& Pate, J. S. (eds) Australian Rushes, Biology, Identification and Conservation of Restionaceae and allied families. (University of Western Australian Press: Nedlands).

Meney, K. A., Dixon, K. W., Scheltema, M. \& Pate, J. S. (1993) Occurrence of vesicular mycorrhizal fungi in dryland species of Restionaceae and Cyperaceae from SW Western Australia. Austral. J. Bot. 41: 733-37.

Meney, K.A. \& Pate, J.S. (1999) Seasonal growth and nutrition of Restionaceae. Pp. 85-96 in Meney, K.A. \& Pate, J.S. (eds) Australian Rushes, Biology, Identification and Conservation of Restionaceae and allied families. (University of Western Australian Press: Nedlands).

Meney, K.A., Pate, J.S., Dixon, K.W., Briggs, B.G. \& Johnson, L.A.S. (1999) Conservation of Australian Restionaceae. Pp. 465-480 in Meney, K.A. \& Pate, J.S. (eds) Australian Rushes, Biology, Identification and Conservation of Restionaceae and allied families. (University of Western Australia Press, Nedlands).

Meney, K. A., Pate, J. S. \& Hickman, E. J.(1999) Morphological and anatomical descriptions of Restionaceae, Anarthriaceae and their distribution. Pp. 161-461 in Meney, K.A. \& Pate, J.S. (eds) Australian Rushes, Biology, Identification and Conservation of Restionaceae and allied families. (University of Western Australian Press: Nedlands).

Pate, J.S. (2000) Fire response and conservation biology of Western Australian species of Restionaceae. Pp. 685-691 in Wilson, K.L. \& Morrison, D.A. (eds) Monocots-Systematics and Evolution (Proc. 2nd Int. Conf. Comparative Biol. Monocots, Sydney 1998). (CSIRO: Melbourne).

Pate, J.S. \& Delfs, J.C. (1999) Anatomical features of Restionaceae and allied families. Pp. 57-70 in Meney, K.A. \& Pate, J.S. (eds) Australian Rushes, Biology, Identification and Conservation of Restionaceae and allied families. (University of Western Australian Press: Nedlands).

Pate, J.S. \& Meney, K.A. (1999) Morphological features of Restionaceae and allied families. Pp. 3-23 in Meney, K.A. \& Pate, J.S. (eds) Australian Rushes, Biology, Identification and Conservation of Restionaceae and allied families. (University of Western Australian Press: Nedlands).

Pate, J. S., Meney, K. A. \& Dixon, K. W. (1991) Contrasting growth and morphological characteristics of fire-sensitive (obligate seeder) and fire-resistant (resprouter) species of Restionaceae (Southern Hemisphere restiads) from south-west Western Australia. Austral. J. Bot. 39: 505-525.

Pate, J. S., Meney, K. A., Dixon, K. W., Bell, T. L., Hickman, E. J. (1999) Response of Restionaceae to fire. Pp. 71-83 in Meney, K. A., Pate, J. S. (eds) Australian Rushes, Biology, Identification and Conservation of Restionaceae and allied families. (University of Western Australian Press: Nedlands).

Rickett, H.W. \& Stafleu, F.A. (1959) Nomina generica conservanda et rejicienda spermatophytorum. Taxon 8: 213-243.

Rudall, P. J. \& Linder, H. P. (1988) Megagametophyte and nucellus in Restionaceae and Flagellariaceae. Amer. J. Bot. 75: 1777-1786. 
Sieler, I.S., Websdane, K.A., Pate, J.S., Meney, K.A. \& Dixon, K.W. (1999) Fungal and insect diseases and incidence of herbivory in Restionaceae. Pp. 109-117 in Meney, K.A. \& Pate, J.S. (eds) Australian Rushes, Biology, Identification and Conservation of Restionaceae and allied families. (University of Western Australian Press: Nedlands).

Vánky, K. (1997) Websdanea, a new genus of smut fungi. Mycotaxon 65: 183-190.

Websdane, K.A., Sieler, I.M., Sivasithamparam, K. \& Dixon, K.W. (1994) Smut and root rots on native rushes (Restionaceae) and sedges (Cyperaceae). J. Roy. Soc. W. Australia 77: 133-137.

Williams, C.A., Harborne, J.B., Greenham, J., Briggs, B.G. \& Johnson, L.A.S. (1997) Flavonoid evidence and the classification of the Anarthriaceae within the Poales. Phytochemistry 45: 1189-1196.

Manuscript received 31 January 2000

Manuscript accepted 15 May 2000 